\title{
KESULITAN BELAJAR SISWA \\ DALAM PEMBELAJARAN BAHASA INDONESIA
}

\author{
Basuki, Yulinda Erma Suryani, dan Dwi Bambang Putut Setiyadi \\ FKIP dan FPsi Universitas Widya Dharma Klaten \\ email: basuki@unwidha.ac.id
}

\begin{abstract}
Abstrak
Penelitian ini bertujuan mendeskripsikan kesulitan belajar siswa dalam proses pembelajaran bahasa Indonesia tingkat SMA. Subjek penelitian siswa SMAN 1 Klaten, SMAN 1 Karangnongko, dan SMAN 1 Karangdowo.Pengumpulan data menggunakan teknik tes dan wawancara. Analisis data menggunakan teknik deskriptif kualitatif dan kuantitatif dengan bantuan komputer program AnBuso. Berdasar hasil analisis data dapat diketahui bahwa siswa mengalami kesulitan pada kompetensi kebahasaan subkompetensi struktur $(61,07 \%)$, kosakata $(52,6 \%)$; kompetensi menyimak $(41,88 \%)$, berbicara $(18,89 \%)$, membaca $(21,15 \%)$, dan menulis $(20,02 \%)$; dan kesastraan baik pada tingkat informasi $(45,69 \%)$, konsep $(40,9 \%)$, perspektif $(41,74 \%)$, dan apresiasi $(47,1 \%)$. Hal itu menunjukkan bahwa kesulitan merata pada berbagai komponen bahan pembelajaran, baik untuk kompetensi kebahasaan maupun kesastraan, maka pencarian solusinya harus bersifat komprehensif termasuk pemilihan metode pembelajaran.
\end{abstract}

Kata kunci: kesulitan belajar, kompetensi, bahasa Indonesia

\section{STUDENTS' LEARNING DIFFICULTIES IN THE INDONESIAN LANGUAGE LEARNING}

\begin{abstract}
This study aims to describe students' learning difficulties in the Indonesian language learning process at the senior high school. The research subjects were students of SMAN 1 Klaten, SMAN 1 Karangnongko, and SMAN 1 Karangdowo. The data were collected by means of tests and interviews. They were analyzed using qualitative and quantitative descriptive techniques with the AnBuso computer program. The results of the data analysis show that the students have difficulties in: the language sub-competencies of structure $(61.07 \%)$ and vocabulary $(52.6 \%)$; the language competencies of listening $(41.88 \%)$, speaking $(18.89 \%)$, reading $(21.15 \%)$, and writing $(20.02 \%)$; and the literary competency at the levels of information $(45.69 \%)$, concepts $(40.9 \%)$, perspectives $(41.74 \%)$, and appreciation $(47.1 \%)$. These show that the difficulties are evenly distributed on the various components of learning materials, both for language and literary competencies, so that the solutions must be comprehensive including the selection of learning methods.
\end{abstract}

Keywords: learning difficulties, competencies, Indonesian language

\section{PENDAHULUAN}

Salah satu upaya untuk mewujudkan pendidikan berkualitas diperlukan adanya sistem penilaian yang dapat dipercaya (credible), dapat diterima (accept- able), dan dapat dipertanggungjawabkan (accountable). Sistem tersebut diwujudkan dalam penyelenggaraan Ujian Nasional (UN) yang diadakan pada jenjang sekolah dasar dan menengah. Ujian Nasional 
merupakan amanah Undang-Undang Nomor 20 Tahun 2003 tentang Sistem Pendidikan Nasional dan amanah PP 19/2005 yang direvisi menjadi PP 32/2013 dan PP 13/2005 tentang Standar Nasional Pendidikan. Adapun tujuan diselenggarakannya UN adalah untuk mengukur pencapaian kompetensi lulusan pada mata pelajaran secara nasional dengan mengacu pada Standar Kompetensi Lulusan (SKL).

Mata pelajaran yang diujikan dalam UN antara lain bahasa Indonesia, bahasa Inggris, Matematika, dan IPA/ IPS. Di antara ketiga mata pelajaran yang diujikan itu, ada mata pelajaran yang hasilnya kurang menggembirakan, bahkan menempati urutan paling rendah, yaitu bahasa Indonesia. Hasil UN SMA/ SMK tahun 2011 da 2012 bahasa Indonesia menempati urutan paling rendah. Nuh mengemukakan bahwa nilai rata-rata pelajaran bahasa Indonesia 7,49 tahun 2011. Nilai maksimum yang diraih siswa 9,90, sedangkan nilai terendah 0,80 . Dibandingkan mata pelajaran lain, nilai rata-rata bahasa Indonesia termasuk yang paling rendah. Tahun 2012, bahasa Indonesia kembali menempati urutan terendah di Jawa Timur, dibandingkan dengan bahasa Inggris dan Matematika (Harahap, 2013). Bahkan, ada pemberitaan yang menyebutkan bahwa hasil UN tahun 2012, pelajar jurusan bahasa yang tidak lulus mata pelajaran bahasa Indonesia 25 persen, sedangkan pelajar dari jurusan IPA yang tidak lulus mata pelajaran bahasa Indonesia hanya sekitar 12 persen dan jurusan IPS sebanyak 19 persen (sinarharapan. co). Dari kondisi itu, mata pelajaran bahasa Indonesia dikatakan sebagai momok yang perlu dicari penyebabnya dengan mendiagnosis kesulitan-kesulitannya dan dicarikan jalan keluarnya.

Idealnya, setiap pelajar dari jurusan Bahasa bisa mendapatkan nilai bagus dari mata pelajaran bahasa Indonesia, sebab bahasa Indonesia selain diajarkan khusus oleh guru-guru bahasa Indonesia, juga ba- hasa ibu dari mayoritas pelajar. Hasil UN tahun 2013 nilai mata pelajaran bahasa Indonesia tidak berbeda jauh dengan hasil UN 2012. Nilai mata pelajaran bahasa Indonesia dari pelajar jurusan Bahasa rata-rata rendah. Fakta ini harus menjadi bahan renungan, tidak hanya guru-guru mata pelajaran bahasa Indonesia, melainkan juga dari pihak perguruan tinggi. Ada apa dengan proses pembelajaran Bahasa Indonesia di Sekolah? Mengapa hasil ujian nasional Bahasa Indonesia lebih rendah dibandingkan Matematika dan Bahasa Inggris? Apakah ada yang salah dengan sistem pembelajaran Bahasa Indonesia? Kesulitan apa yang dihadapi siswa dalam proses pembelajaran Bahasa Indonesia?

Dari pertanyaan-pertanyaan di atas kiranya dapat dilakukan jalan keluarnya, yaitu dengan cara mendiagnosis kesulitan belajar siswa misalnya. Kesulitan belajar yang dialami siswa hendaknya harus segera diatasi karena akan berpengaruh terhadap pemahaman siswa. Oleh karena itu, bila siswa mengalami kesulitan belajar pada salah satu materi atau pokok bahasan, sangat besar kemungkinan siswa akan mengalami kesulitan saat mempelajari materi berikutnya. Selain itu, jika kesulitan yang dialami tidak segera ditangani, dikhawatirkan siswa akan terus mengalami kegagalan dalam belajar. Kegagalan tersebut akan menimbulkan kekecewaan, malas belajar, rendah diri atau bahkan mungkin dapat mempengaruhi jiwanya (Winiaril, 2015).

Kesulitan pada materi pelajaran merupakan kesulitan yang paling berpengaruh pada mutu hasil belajar. Ketidakmampuan siswa menguasai materi pelajaran merupakan masalah yang perlu dicari penyelesaiannya, sehingga progam pembelajaran sesuai dengan standar kompetensi yang ditetapkan. Permasalahan yang muncul adalah cara mengetahui dan memperoleh informasi tentang kesulitan belajar siswa. Materi ajar atau bahan ajar bahasa Indone- 
sia secara umum harus disesuaikan pada setiap jenjang pendidikan. Tujuannya agar bahan ajar tersebut sesuai dengan kebutuhan siswa, guru, serta kurikulum yang telah ditentukan (Febriani, 2012).

Diagnosis tentang kesulitan belajar siswa perlu dilakukan untuk mengungkapkan prestasi siswa. Setelah kegiatan diagnosis, selanjutnya dilakukan tes diagnostik. Tes diagnostik dilakukan sebelum atau selama masih berlangsungnya kegiatan belajar mengajar. Tes diagnostik sengaja dirancang sebagai alat untuk menemukan kesulitan belajar yang dihadapi siswa (Fortuna, dkk, 2013). Tujuan dari tes ini untuk menentukan bahan-bahan pelajaran tertentu yang masih menyulitkan siswa. Siswa yang masih mengalami kesulitan dalam hal tertentu diremidi dan diberi tugas mengerjakan atau mempelajari bahan pengajaran program remedial (Nurgiyantoro, 2016; Depdiknas, 2003, Hadi, dkk, 2015).

Hasil analisis ini berupa daftar kompetensi dasar, materi dan indikator yang sudah dan belum dikuasai oleh sebagian peserta didik. Informasi ini digunakan untuk perbaikan progam pembelajaran sampai peserta didik memiliki kompetensi dasar. Jika semua siswa sudah menguasai suatu kompetensi dasar, materi dan indikator maka pelajaran dapat dilanjutkan dengan materi berikutnya dan apabila siswa belum menguasai kompetensi dasar, materi atau indikator maka guru memberikan progam pengajaran remidial. Oleh karena itu perlu dilakukan kajian terhadap kompetensi yang belum dikuasi siswa dalam pembelajaran Bahasa Indonesia.

\section{METODE}

Metode penelitian yang digunakan adalah penelitian dan pengembangan Research and Development(R \&D) (Borg \& Gall, 1983). Penelitian ini berorientasi pada pengembangan suatu produk yang proses pengembangannya dideskripsikan secara teliti dan produk yang diperoleh, dievaluasi. Jenis Penelitian ini digunakan untuk memvalidasi dan mengembangkan produk. Rangkaian penelitian dan pengembangan dilakukan dimulai dengan eksplorasi dan studi konseptual, dilanjutkan dengan ujicoba dan evaluasi serta implementasi (Sugiyono, 2016).

Subjek penelitian sebanyak 709 siswa dengan rincian 318 orang siswa SMAN 1 Klaten, 256 orang siswa SMAN 1 Karang Dowo, dan 135 orang siswa SMAN 1 Karang Nongko. Teknik pengumpulan data menggunakan tes dan wawancara. Tes dilakukan untuk memperoleh data tentang diagnosis kesulitan belajar siswa dalam pembelajaran Bahasa Indonesia. Wawancara dilakukan kepada siswa untuk menggali informasi mengenai kesulitan yang dialami siswa dalan pelajaran bahasa Indonesia.

Teknik analisis data penelitian terdiri atas dua jenis, yaitu data yang bersifat kualitatif dan kuantitatif. Data kualitatif meliputi deskripsi data mengenai kesulitan siswa dalam pebelajaran Bahasa Indonesia. Analisis kuantitatif menggunakan teknis analisis statistik sederhana. Teknik analisis statistik sederhana yang dimaksud berupa analisis persentase (Arikunto, 2003). Teknik analisis ini digunakan peneliti untuk menghitung persentase skor pencapaian siswa dan untuk menghitung persentase kesalahan yang dilakukan siswa dalam menjawab tes diagnostik dalam pembelajaran Bahasa Indonesia. Teknik analisis dilakukan dengan menggunakan bantuan komputer program AnBuso.

\section{HASIL DAN PEMBAHASAN Hasil}

Diagnosis kesulitan Belajar Bahasa Indonesia dilakukan di tiga sekolah yaitu SMAN 1 Klaten, SMAN 1 Karang Nongko dan SMAN 1 Karang Dowo. Hasil analisis tingkat kesulitan belajar yang dialami siswa dalam pembelajaran Bahasa 
Indonesia dengan menggunakan bantuan komputer program AnBuso dapat dilihat pada Gambar 1.

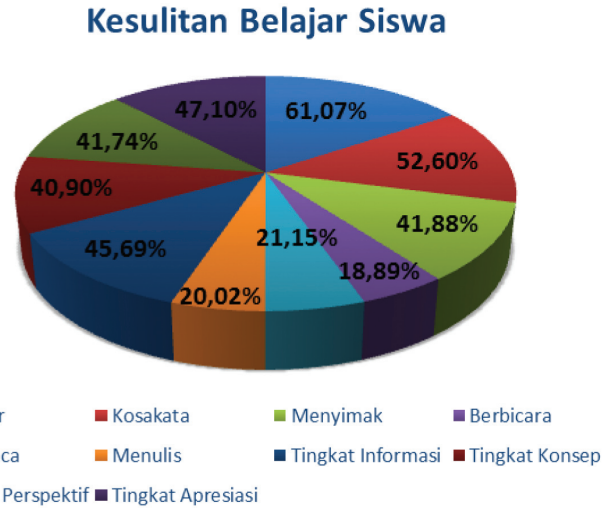

Grafik 1. Tingkat Kesulitan Belajar Siswa

Siswa mengalami kesulitan paling banyak pada kompetensi kebahasaan subkompetensi struktur bahasa, sedangkan yang paling sedikit mengalami kesulitan pada kompetensi keterampilan berbahasa subkompetensi berbicara.

Berdasarkan hasil wawancara yang dilakukan terhadap siswa, dapat diketahui bahwa siswa mengalami kesulitan dalam pembelajaran Bahasa Indonesia pada materi pemahaman peribahasa, menafsirkan puisi, penggunaan tata bahasa Indonesia yang baik dan benar, menangkap isi dan memahami teks bacaan yang harus dikaitkan dengan pertanyaan-pertanyaan yang dibuat oleh pembuat soal, dan menulis.

\section{Pembahasan}

Bahasa Indonesia merupakan bahasa persatuan yang menjadi identitas bangsa Indonesia. Salah satu cara untuk menjaga kelestarian dan kemurnian bahasa Indonesia adalah dengan menuliskan kaidahkaidah ejaan dan tulisan bahasa Indonesia dalam sebuah buku yang di-sebut dengan Pedoman Umum Ejaan Bahasa Indonesia yang Disempurnakan (PUEYD) (2016). PUEYD dapat digunakan sebagai pedoman dalam kegiatan berkomunikasi menggunakan bahasa Indonesia dengan benar dalam komunikasi yang sifatnya formal. Selain itu, juga ada buku-buku pedoman yang lain seperti Pedoman Umum Pembentukan Istilah (2006), Tata Bahasa Baku Bahasa Indonesia (2000), Kamus Besar Bahasa Indonesia (2002), Undang-Undang Republik Indonesia Nomor 24 Tahun 2009 tentang Bendera, Bahasa, dan Lambang Negara, serta Lagu Kebangsaan (2011), dan sebagainya.

Salah satu tujuan utama pengajaran bahasa adalah mempersiapkan siswa untuk melakukan interaksi yang bermakna dengan bahasa yang alamiah. Agar interaksi dapat bermakna bagi siswa, perlu didesain secara mendalam program pembelajaran bahasa Indonesia. Desain yang bertumpu pada kontekstual, konstruktif, komunikatif, intergratif, dan kuantum yang didasari oleh kompetensi dasar siswa. Kemampuan berbahasa Indonesia berarti siswa terampil menggunakan bahasa Indonesia sebagai alat komunikasi. Terampil berbahasa berarti terampil menyimak, berbicara, membaca, dan menulis dalam bahasa Indonesia (Ripai, 2012). Menghayati bahasa dan sastra Indonesia berarti siswa memiliki pengetahuan bahasa dan sastra Indonesia, dan memiliki sikap positif terhadap bahasa dan sastra Indonesia.

Dignosis terhadap kesulitan belajar yang dialami siswa pada Tingkat SMA dilakukan dengan menggunakan tes diagnotik. Perangkat tes diagnostik dalam pembelajaran Bahasa Indonesia yang digunakan mencakup kompetensi yang harus dikuasai siswa dalam pembelajaran Bahasa Indonesia yaitu kompetensi kebahasaan, keterampilan berbahasa dan kesastraan. Ketiga kompetensi tersebut terdiri atas beberapa subkompetensi. Kompetensi kebahasaan terdiri atas subkompetensi struktur dan subkompetensi kosakata. Kompetensi keterampilan berbahasa terdiri atas subkompetensi menyimak, subkompetensi berbicara, sub komptensi membaca dan subkompetensi menulis. Kompetensi kesastraan terdiri atas subkompetensi tingkat informasi, 
subkompetensi tingkat konsep, subkompetensi tingkat perspektif dan subkompetensi tingkat apresiasi.

Pada subkompetensi menulissiswa mengalami kesulitan dalam mengembangkan gagasannya. Ketika mereka harus menuangkan gagasannya dalam bahasa tulis, mereka mengalami kebuntuan. Misalnya, ketika menulis sebuah puisi atau menulis sebuah cerita, siswa merasa kesulitan. Ketika siswa menulis puisi mereka memerlukan tingkat abstraksi yang tinggi. Abstraksi yang tinggi diperoleh apabila siswa menuliskan topiknya dengan cara mengamati secara langsung objek tersebut, bukan dengan imaginasi saja. Apabila siswa hanya berimaginasi akibatnya siswa mengalami kesulitan ketika harus menulis puisi. Dalam menulis siswa juga memerlukan pengamatan mengenai objek yang akan ditulis.

Di sinilah pentingnya menghubungkan bahasa dengan konteks pemakaiannya (Sumarti, 2010). Konteks yang dimaksud dapat berupa konteks lingkungan, konteks sosial, dan konteks budaya mengingat Indonesia memiliki kebudayaan yang multikultural. Model pembelajaran berkonteks multikultural perlu diimplementasikan di sekolah untuk meningkatkan kecerdasan emosi peserta didik (Zulaeha, 2013). Disamping itu, siswa juga harus memiliki kosa kata dan pengetahuan tentang dunia (knowledge atau knowledge of the world) agar dapat menuliskan apa yang diamati (Kartamiharja, 2000; Alwi, 2000; Van Dijk, 1997). Apabila seorang siswa memiliki hal itu, ia tidak akan kehabisan kalimat untuk menuangkan gagasan-gagasan berdasarkan data-data yang diamati.

Selain itu, siswa juga mengalami kesulitan pada saat ujian baik ujian formatif maupun sumatif pada saat diberikan soal dalam bentuk wacana. Siswa diminta untuk membaca teks paragraf pendek, setelah itu siswa harus menjawab pertanyaan berdasarkan teks yang ada. Teks-teks yang merupakan bacaan dalam soal-soal ujian memerlukan pemahaman secara cepat dengan cara membaca cepat pula. Kecepatan membaca penting, karena waktu yang disediakan untuk mengerjakan soal sangat terbatas. Jadi, dia harus menyelesaikan membaca teks dengan perhitungan waktu yang matang sekaligus dengan pemahaman akan isi bacaan. Kecepatan membaca harus sering dilatihkan kepada siswa agar mereka memiliki kecepatan membaca yang tinggi.

Guru perlu melatihkan hal itu agar para siswanya dapat menyelesaikan bacaan-bacaan dalam soal ujian yang begitu banyaknya dengan waktu yang tepat, sehingga waktu tidak dihabiskan untuk memahami sebuah bacaan. Ada bukubuku yang berisi mengenai teori membaca cepat dengan ukuran waktu berdasarkan rumus-rumus yang telah diuji untuk mengukur kecepatan membaca seseorang. Guru dalam menerapkan metode, sekali lagi, harus tepat sehingga siswa benarbenar mendapatkan suatu pengetahuan tentang membaca cepat. Petunjuk paling jelas dari tingkat kemampuan membaca seseorang adalah kecepatan membacanya (Nurhadi, 2005).

Pada tingkat SMA materi pembelajaran bahasa Indonesia sudah mengalami pengembangan sehingga cakupan materinya lebih banyak daripada pembelajaran Bahasa Indonesia di SMP. Pada tingkat SMA kompetensi berbahasa meliputi: kompetensi kebahasaan, keterampilan berbahasa, dan kesastraan. Kompetensi kebahasaan secara garis besar dapat dikelompokkan menjadi struktur dan kosakata. Sasaran struktur ini meliputi pemahaman dan penggunaan pembentukan kata, frasa, dan kalimat. Kompetensi keterampilan bahasa meliputi kemampuan mendengar, membaca, menulis dan berbicara. Secara umum kompetensi kesastraan dapat berupa pengetahuan tentang sastra dan kemampuan apresiasi sastra.

Kesulitan yang dihadapi oleh para siswa dalam memahami makna periba- 
hasa dapat dipecahkan antara lain dengan mengajak siswa untuk mencari makna peribahasa dari sumber pustaka. Ada buku-buku yang berisi tentang makna peribahasa atau majas. Majas, kiasan, atau figure ofspeech adalah bahasa kias, bahasa indah untuk meninggikan dan meningkatkan efek dengan memperkenalkan serta membandingkan benda atau hal tertentu dengan benda atau hal lainyang lebih umum (Tarigan, 2009). Peribahasa sifatnya klise, sehingga maknanya tidak berubah. Untuk itu diperlukan pemahaman maknamakna tersebut dengan menghafalkan. Ada buku-buku yang bisa dipakai oleh guru untuk memberikan pengetahuan makna peribahasa kepada siswa. Selain itu makna peribahasa juga dapat dilihat pada Kamus Besar Bahasa Indonesia. Guru harus memberitahu makna-makna tersebut dalam kamus dengan cara meminjamkan kamus tersebut kepada siswa.

Selanjutnya dalam menafsirkan puisi, seorang siswa juga harus mengetahui makna batiniah atau makna yang tidak sebenarnya yang tersebunyi di dalam sebuah puisi (Djojosuroto, 2005). Makna yang tersembunyi itu hanya dapat diketahui oleh para siswa apabila mereka sering diberikan tugas untuk menafsirkan macam-macam puisi. Untuk menafsirkan apa yang dimaksud oleh peyair dalam karya-karyanya, siswa juga perlu mengenal karakter seorang penyair dalam menulis puisi. Antara penyair yang satu dengan penyair yang lain memiliki kekhasan sendiri-sendiri. Ada penyair yang suka menulis puisi yang bersifat religius, ada yang suka menulis puisi kepahlawanan, puisi tentang keindahan alam, puisi yang berisi kritik sosial, puisi cinta, dan sebagainya. Dari mengenal karakter, seorang pembaca bisa lebih mudah menafsirkan sebuah puisi. Pemahaman tentang makna gramatikal atau makna konteks itu juga harus dibimbing oleh guru. Jangan sampai guru yang mengajarkan materi itu juga tidak memahami maknanya. Pemahaman tersebut dapat dilakukan dengan cara menafsirkan secara bersama-sama apa yang sebenarnya dimaksud oleh seorang sastrawan dalam puisinya itu.

Pemahaman tentang bahasa Indonesia yang baik dan benar, memerlukan pengetahuan tentang apakah bahasa Indonesia yang baik dan benar itu (Arifin, 2000). Bahasa Indonesia yang baik artinya pemakaian bahasa Indonesia yang sesuai dengan situasinya. Misalnya bercakapcakap dalam situasi nonformal dalam sebuah keluarga atau di pasar tidak perlu memakai bahasa yang benar, tetapi cukup memakai bahasa yang komunikatif. Pemakaian bahasa Indonesia yang benar mengacu kepada pemakaian bahasa Indonesia yang sesuai dengan kaidah. Ada beberapa kaidah pemakaian bahasa Indonesia seperti telah disebutkan di atas.

Bahasa Indonesia diajarkan di setiap jenjang pendidikan mulai dari jenjang sekolah dasar, menengah, sampai ke perguruan tinggi. Pengajaran bahasa Indonesia sudah dilaksanakan secara ekstensif dalam lembaga pendidikan formal,namun hasilnya belum memuaskan. Kemampuan berbahasa Indonesia para siswa lulusan SD, SMP, ataupun SMA belum memadai. Bahkan, hal ini juga terjadi di perguruan tinggi. Para dosen pembimbing skripsi sering mengeluh karena kemampuan berbahasa mahasiswanya kurang memuaskan. Bahasa sangat penting bagi manusia, oleh karena itu perlu pembenahan dan pemantapan dalam pengajaran bahasa Indonesia. Pemantapan pengajaran harus berlangsung serempak pada setiap jenjang pendidikan. Pengajaran bahasa harus menghasilkan siswa-siswa yang terampil menggunakan bahasa Indonesia sebagai sarana komunikasi. Terampil berbahasa bermakna terampil menyimak, berbicara, membaca, dan menulis dalam bahasa Indonesia.

Proses belajar mengajar mencakup sejumlah komponen. Komponen proses belajar mengajar tersebut adalah siswa, 
guru, tujuan, bahan, metode, media, dan evaluasi. Salah satu kelemahan dalam pengajaran bahasa adalah dalam komponen metode. Berdasarkan hasil wawancara dengan siswa dapat diketahui bahwa siswa merasa bosan belajar Bahasa Indonesia karena dalam memberikan materi pelajaran guru lebih banyak menggunakan metode ceramah. Cara mengajar guru sangat berpengaruh kepada cara belajar siswa. Bila guru mengajar hanya dengan metode ceramah maka dapat diduga siswa belajar secara pasif dan hasilnya pun berupa pemahaman materi bersifat teoritis. Oleh karena itu, guru bahasa Indonesia harus mengenal, memahami, menghayati, dan dapat mempraktikkan berbagai metode pengajaran bahasa.

Tarigan (1994) mengemukakanbahwa minimal ada 14 metode yang pantas dikuasai oleh guru, yaitu: metode penugasan, metode eksperimen, metode proyek, metode diskusi, metode widyawisata, metode bermain peran, metode demonstrasi, metode sosiodrama, metode pemecahan masalah, metode tanya jawab, metode latihan, metode ceramah, metode bercerita, dan metode pameran. Di antara keempatbelas metode tersebut tidak semua metode cocok digunakan sebagai metode pengajaran bahasa Indonesia, tetapi sebagian di antaranya dapat digunakan sebagai metode pengajaran bahasa Indonesia. Metode bersifat netral, tidak ada metode yang baik dan dan tidak ada metode yang jelek. Baik atau buruknya sesuatu metode ditentukan oleh guru yang menggunakan metode tersebut. Bila guru dapat menggunakan metode tersebut, metode itu menjadi baik. Sebaliknya, bila guru menggunakan metode itu secara tidak tepat, metode itu pun menjadi tidak baik.

Guru diharapkan dapat memilih dan menerapkan metode pengajaran yang tepat dalam setiap proses belajar mengajar di kelas. Metode yang dipilih dan diterapkan harus sesuai dengan tujuan pembelajaran, bahan pembelajaran, keadaan siswa seperti kemampuan, minat, dan lingkungannya. Metode pengajaran itu harus pula bervariasi dan memberikan pengalaman berbahasa yang beraneka bagi siswa, merangsang siswa untuk belajar, serta memudahkan siswa memahami bahan pembelajaran. Metode yang dipilih pun harus mudah dioperasikan dan tidak menuntut peralatan yang rumit.

Kemampuan berbahasa Indonesia berarti siswa terampil menggunakan bahasa Indonesia sebagai alat komunikasi. Terampil berbahasa berarti terampil menyimak, berbicara, membaca, dan menulis dalam bahasa Indonesia. Dengan demikian ada berbagai pendekatan dalam pembelajaran bahasa Indonesia untuk menunjang terlaksananya tujuan pembelajaran bahasa Indonesia agar siswa terampil berbahasa.

Muslimin (2011) mengemukakan bahwa rendahnya mutu atau kualitas pembelajaran bahasa dan sastra Indonesia di sekolah selama ini disebabkan oleh banyak hal, mulai dari kurikulum, guru, siswa, sarana prasarana, dan pemerintah sebagai pengambil kebijakan terkait dengan pendidikan. Beberapa permasalahan yang selama ini menggangu semangat belajar siswa diantaranya: keseragaman kurikulum, pembelajaran yang berpusat pada guru, beban administrasi guru yang tinggi, dan jumlah siswa dalam satu kelas terlalu besar sehingga perlu dicarikan solusi. Oleh karena itu, guna mewujudkan pembelajaran bahasa dan sastra Indonesia yang berorientasi pada siswa, maka dalam pembelajaran Bahasa Indonesia perlu dilakukan inovasi yang terkait dengan pembelajaran, antara lain: (1) inovasi kurikulum, (2) inovasi pembelajaran, dan (3) Inovasi manajemen kelas. Dengan dilakukan inovasi terhadap sistem pembelajaran bahasa dan sastra Indonesia, semangat dan gairah guru, siswa, serta semua stakeholder pendidikan dapat bangkit kembali sehingga bahasa dan sastra Indonesia menjadi salah mata 
pelajaran prioritas bagi generasi kita yang akan datang.

\section{SIMPULAN}

Berdasar hasil analisis data dapat disimpulkan bahwa siswa mengalami kesulitan pada kompetensi kebahasaan subkompetensi struktur sebanyak 61,07\% dan 52,6\% pada subkompetensi kosakata. Pada kompetensi keterampilan berbahasa, siswa yang mengalami kesulitan belajar pada subkompetensi menyimak sebesar $41,88 \%$, pada subkompetensi berbicara $18,89 \%$, pada subkompetensi membaca sebanyak $21,15 \%$ dan pada subkompetensi menulis sebesar 20,02\%. Siswa mengalami kesulitan belajar pada kompetensi kesastraan subkompetensi tingkat informasi sastra sebanyak $45,69 \%$, pada subkompetensi tingkat konsep sastra sebanyak $40,9 \%$, pada subkompetensi tingkat perspektif sastra sebanyak $41,74 \%$, dan pada subkompetensi tingkat apresiasi sastra sebanyak $47,1 \%$. Hal itu menunjukkan bahwa kesulitan merata pada berbagai komponen bahan pembelajaran, maka pencarian solusinya harus bersifat komprehensif termasuk pemilihan metode pembelajaran.

\section{UCAPAN TERIMA KASIH}

Artikel ini ditulis berdasarkan laporan penelitian hibah bersaing Tahun 20152016. Oleh karena itu, kami ucapkan terima kasih kepada DP2M DIKTI yang telah memfasilitasi pendanaan dalam kegiatan penelitian ini. Ucapan terima kasih kami sampaikan kepada siswa beserta guru SMAN 1 Klaten, SMAN 1 Karangnongko, SMAN 1 Karangdowo, Kabupaten Klaten yang telah meluangkan waktu untuk menjadi responden dalam penelitian ini.

\section{DAFTAR PUSTAKA}

Alwi, Hasan, dkk. 2000. Tata Bahasa Baku Bahasa Indonesia. Jakarta: Balai Pustaka.
Arifin, E. Zaenal dan S. Amran Tasai. 2000. Cermat Berbahasa Indonesia. Jakarta: Akademika Pressindo.

Arikunto, Suharsimi. 2003. Dasar-dasar Evaluasi Pendidikan. Jakarta: Bumi Aksara.

Badan Pengembangan dan Pembinaan Bahasa. 2011. Undang-Undang Republik Indonesia Nomor 24 Tahun 2009 tentang Bendera, Bahasa, dan Lambang Negara, serta Lagu Kebangsaan. Jakarta: Kemendikbud.

Borg, Walter R dan Meredith Damien Gall. 1983. Educational Research: An Introduction. New York: Longman.

Depdiknas. 2003. Pedoman pengembangan Tes Diagnostik Sains SMP. Jakarta: Direktorat Pendidikan Lanjutan Pertama, Direktorat Jenderal Pendidikan Dasar dan Menengah.

Djojosuroto, Kinayati. 2005. Puisi: Pendekatan dan Pembelajaran. Bandung: Nuansa.

Febriani, Meina. 2013. "Pengembangan Bahan Ajar Apresiasi Dongeng Banyumas Bagi Siswa SD Kelas Rendah", Jurnal Pendidikan Bahasa dan Sastra Indonesia 1 (1).

Fortuna R, Dewi; Edi Chandra, dan Ria Yulia Gloria. 2013. "Pengembangan Tes Diagnostik untuk Mengkur Miskonsepsi Siswa pada Pokok Bahasan Sistem Regulasi Manusia untuk Siswa SMA Kelas XI, Semester II", Jurnal Scientiae Education, Volume II.

Hadi, Samsul; K. Ima Ismara; dan Effendie Tanumihardja. 2015. "Pengembangan Sistem Tes Diagnostik Kesulitan Belajar Kompetensi Dasar Kejuruan Siswa SMK", Jurnal Penelitian dan Evaluasi Pendidikan, Volume 19, Nomor 2, hlm. 169-175.

Harahap, Rian. 2013. "Bahasa Indonesia Momok Menakutkan", kompasiana. com, 18 Februari 2013.

Kartamihardja, S. 2000. "Analisis Wacana dalam Pengajaran Bahasa". Jurnal Ilmiah Masyarakat Linguistik Indonesia, 
Tahun 18, Nomor 1, hal. 123-140. Jakarta: Lembaga Bahasa Unika Atmajaya.

Muslimin. 2011. “Perlunya Inovasi dalam Pembelajaran Bahasa dan Sastra Indonesia". Jurnal Bahasa, Sastra, dan Budaya. Vol. 1, No.1.

Nurgiyantoro, Burhan. 2016. Penilaian Pembelajaran Bahasa Berbasis Kompetensi. Yogyakarta: BPFE-Yogyakarta.

Nurhadi. 2005. Bagaimana Meningkatkan Kemampuan Membaca: Suatu Teknik Memahami Literatur yang Efisien. Bandung: Sinar Baru Algensindo.

Panitia Pengembang Bahasa Indonesia. 2006. Pedoman Umum Pembentukan Istilah. Jakarta: Pusat Bahasa.

Ripai, Ahmad. 2012. "Pengembangan Teknik Berpikir Berpasangan Berbagi Pembelajaran Menulis Teks Drama yang Bermuatan Nilai-nilai Pendidikan Karakter Pada Mahasiswa Pendidikan Bahasa dan Sastra Indonesia", Seloka: Jurnal Pendidikan Bahasa dan Sastra Indonesia 1 (2).

Sugiyono. 2016. Metode Penelitian dan Pengembangan (Research and Development/ $R \& D$ ). Bandung: Alfabeta.
Sumarti, Endang. 2010. “Analisis Wacana Kritis Strategi Politik Penggunaan Bahasa dalam Pidato Presiden Susilo Bambang Yudhoyono", Litera: Jurnal Penelitian Bahasa, Sastra, dan Pengajarannya, Volume 9, Nomor 1, hlm. 19-39.

Tarigan., Guntur H. 1994. Membaca Ekspresif. Bandung: Angkasa. 2009. Pengajaran Semantik. Bandung: Angkasa.

Van Dijk, Teun A. 1997. Discourse as Social Interaction. London: SAGE Publications.

Winiaril, I G A., Meter, I G., Oka, I G A N.2015. "Analisis Kesulitan-Kesulitan Belajar Bahasa Indonesia Kelas V dalam Implementasi Kurikulum 2013 di SD Piloting Se-Kabupaten Gianyar". Jurnal PGSD. Vol. 3, No.1.

Zulaeha, Ida. 2013. "Pengembangan Model Pembelajaran Keterampilan Berbahasa Indonesia Berkonteks Multikultural", Litera: Jurnal Penelitian Bahasa, Sastra, dan Pengajarannya, Volume 12, Nomor 1, hlm. 97-105. 